\title{
The Business Model: Implications for University Management in Nigeria in an Era of Underfunding
}

\author{
Professor Victor F. Peretomode \\ Professor of Educational Administration and Higher Education, Faculty Of Education, Delta State University, \\ Abraka, Delta State, Nigeria.
}

\begin{abstract}
The chief executives of public universities in Nigeria are not finding it interesting managing their institutions. There is an increase in enrolment, even greater increase in the cost of providing necessary soft and hard facilities and infrastructure to support basic teaching and learning and research. While so much funds are required, these universities are under tremendous pressure from students, parents and government not to increase tuition fees or increase charges for other student related activities. Yet, there have been a great reduction in State funding. The proprietors of these institutions even expect them to, and infact charge them to do more for themselves by way of ingeniously looking for alternative sources of funding other than charging fees and expecting government support.The chief executives are in a dilemma. In the face of financial strangulations what should these Vice-Chancellors do? This paper posits that it will be necessary for the ViceChancellors of public Universities in Nigeria to adopt an appropriate reformed business model in the management of their institutions. This paper therefore explains the concept and outlines a number of business models, highlights the strengths and limitations and discusses the implications, and applications of business model in the management of universities in order to achieve their triple missions of teaching and learning, research and extension services.
\end{abstract}

Key Terms: Business models, efficiency, mixed technologies, online learning, private for-profit, public universities.

\section{Introduction}

The university belongs to the level of education referred to as tertiary or higher education or postsecondary education. It is the highest cadre at this level. Generally considered as an example of complex organization, there are different types- private for-profit or private non-for-profit, public (federal government or state owned), and specialized or non-specialized. Although diversified in type, they have certain common features that distinguish them from other organizations, including business organizations. Some of the distinguishing characteristics are ambiguous and unclear goals, active client participation, fragmented professionalism, academic freedom, fluidity of participation, unclear technology and difficulty in determining or measuring its profit and quality of its products. Generally, their mission and objectives include teaching and learning, advancement of knowledge through research and extension or community services. They are also concerned with refinement of knowledge and being custodian of culture. They may differ in degree in terms of focus.

University governance has evolved through various model types-bureaucratic, collegiality, political and through business to entrepreneurial models. Although public or non-for profit universities are not exactly business organizations, the business model has come to be applied in the management of public universities and non-public universities as well. But how workable is this business model in University governance? This paper posits that the business model may be relevant and in fact appropriate in university management in Nigeria especially in this era of State underfunding of its universities because one common concern of public and private for-profit or business organization is how best to have sustainable revenue for running the organization in order to continue to grow and remain in business. This paper, therefore, will examine what the business model means, its strengths and weaknesses and implications and conclude on its appropriateness in the management of universities in Nigeria.

\section{The Business Model}

The term Business Model has become a buzzword that everybody uses or sometimes overused. It is therefore not surprising that there is no one generally accepted meaning of the word. Again there are several business models and this has added to the confusion and frustration (en.wikipedia.org.,2014). Alt and Zimmerman (2001) have opined that the term "business model" has not been consistently defined, and that a consensus of the elements of the business models was lacking. Therefore, it will not be out of place to provide several of the definitions in order to deduce some of the elements and then deduce those that can be applied in higher education. 
According to Vitez (2013), a business model is an outline of specific processes, functions or activities a company uses to produce customers goods and services in the business environment in the most efficient and effective way. Wikipedia (2014) sees it as the design of organizational structures to enact a commercial opportunity and to describe the rationale of how an organization creates, delivers and captures values in economic, social, cultural or other contexts. Stewart and Zhao (2003) simply defined business model as a statement of how a firm will make money and sustains its profit stream over time. To Slywotzky (1996), a business model is the totality of how a company selects its customers, defines and differentiates its offerings, defines the tasks it will perform itself and those it will outsource, configures its resources, goes to market, creates utility for customers and captures profits. Osterwalder, Pigneur and Tucci (2003) defines it as "a blueprint of how a company does business" while Mayo and Brown (1999) refer to a business model as the design of key interdependent systems that create and sustain a competiveness. It is a plan for earning a profit the money left over from sales revenue after paying all expenses (Ingram, 2014).

Further, a business model is considered as "a representation of a firm's underlying core logic and strategic choices for creating and capturing value within a value network" (Shafer, Smith and Linder, 2005:202). It concerns how "a firm creates value, the internal source of the firm's advantage and how the firm will capture value" (Brink and Holmen, 2009:109). It is a design of a business which focuses on how revenue will be generated (chow.com/facts...html, 2014) to sustain itself.

From the above definitions, it can be argued that business models:

1. Are plan or blueprint for creating, delivering, capturing value and for generating the revenue it needs to cover costs.

2. Operate to generate profit.

3. Are concerned with efficiency and effectiveness.

4. Are concerned with how the organization makes his money and sustains its profit and itself.

5. Are concerned with creating value

6. Are concerned with increased productivity.

7. Serve to Contain costs at the same time improving outcomes (Sheets, Crawford and Soares, 2012).

\section{Elements of Business Model}

Sheets, Crawford and Soares (2012) have identified four core elements of business models. These are a customer value proposition, value chain, a profit formula and a competitive strategy. A customer's value proposition explains how an organization addresses customers' needs through a product or service it offers. A value chain organizes processes, partners and resources to deliver the value proposition. A profit formula lays out how an organization will generate enough revenue to more than cover costs. A competitive strategy details how an organization will compete with rivals and defend its position in the value network. The authors added that every organization, including higher education, features only a few of the many possible combinations of these four elements - the few are normally referred to as the organization's dominant business models (ibid, 2012).

\section{Business Models}

There are numerous types of business models. Bolaji (2011) provided probably the most comprehensive list of business models when he identified 24 of such models which he categorized into two namely traditional business models and new business models. Ten (10) of the models fall under the traditional classification and the others (14) under the new models category.

\section{Table 1: Categorization of Business Models into Two}

Traditional Business Models

1. Creator of a physical good - a service or a virtual good - and sells it either directly to the customer or to a distributor. This is the most fundamental of the business models.

2. Distributor of goods and services.

3. Franchise model

4. Razer and blades model. In this model, the seller sells one product for free or very low cost hoping to sell a complementary product at high margins.

5. Brokerage/market place model

6. Landlord model for renting products and services. The business rents a physical location or a product for a specific period for a fee. E.g. DVD rentals.

7. Advertisement based model for content.

8. Subscription based model e.g. home rental

9. Lead generation and affiliate marketing
New Business Models

1. Listing fee model e.g. job listing

2. Selling customer data - a model used by business that have large user base and plenty of useful information.

3. Micropayment for content

4. Fermium model

5. Crowd sourcing model

6. Open sourcing customization and maintenance

7. No-frills model

8. Network effect model

9. Pay with social currency 


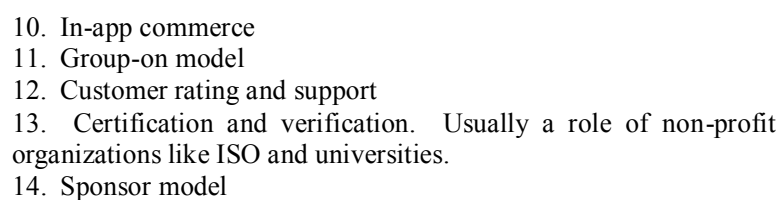

Source: Summarized from the works of V.Balaji (2011). How to build revenue: 24 types of business models with examples. The Agni.com. December 2nd.

All the business models described by Bolaji (2011) are not quite applicable to higher education, except one, the certification and verification model. As the author himself later pointed out, these models are more or less pure business models for business firms on how to build revenue. But it should be noted that how organizations make money or generate revenue is only an aspect of university management. The models are concerned with what a business does and how it makes money doing that.

The many business models have been categorized into four primary models by Nelson (2011). He described the four as follows:

1. Shop Keeper. This in the view of Nelson (2011), is the oldest and most basic and straightforward of the business models. It simply involves establishing a store and filling it with products and waiting for customers to come. This model while still being used today, "is not as useful as it once was."

2. Direct Sales. This model involves selling and marketing directly to the customer away from a fixed location. That is, the business representative goes to the customer to sell products.

3. Bait and Hook. This model is akin to the one Bolaji referred to as Razer and Blades model. Typically, according to Nelson (2011), this business model involves "offering a product for free or very low price but then selling component products at a high price to a customer once they are hooked." A good example often cited are jet-ink printers; the printer is inexpensive but the ink cartridges are expensive and you must buy ink cartridge at a high price to keep the printer working.

4. Industrialization of Services. This business model involves turning a service into an industry. A typical example cited by Nelson (2011) is "law and accounting firm which can come together and help each other out in the provision of services to clients" or an architectural and engineering firms banning together to provide services to clients.

Again, this classification is not very useful and applicable to higher education as only very little elements of direct sales model may be applied. However, the business models proposed by Sheets, Crawford and Soars (2012) seem to be more appropriately related to higher education.

Sheets, Crawfrord and Soars (2014), like Nelson (2011), identified four business models namely open business model, multisided models, unbundled models and facilitated network models. Open business models are considered by the authors and Henry Chesbrough (2011) as involving the use of external as well as internal ideas and resources to create and capture value for an organization. Seers and his colleagues (2014) described multisided models as those that "create value by facilitating interactions between interdependent groups of customers/clients such as application developers and users on the platforms". They added that higher education institutions are example of this model. This is to the extent that they leverage the interdependencies between employers and students in providing learning and credentialing services and some others "also leverage the interdependencies between businesses in commercializing university research and government funders interested in accelerating technology and economic development" (Seers, et al, 2014).

The unbundled models, according to Seers et al (2014), separate three core business functions that require different types of organizational expertise. These are customer - relationship management which focuses on customer acquisition and retention; in-product innovation business focuses on constant development of products and services that can be promoted; infrastructure management business which integrates or combines two functions with an infrastructure platform that can support large volumes of transactions and thereby achieve economies of scale. And the facilitated network models can be used to "enable customers to better access and use the most appropriate mixture of products and services offered by multiple organizations". Seers et al (2014) cited the example in higher education where there are now organizations that provide career and educational planning services directly to students who are searching for and applying to higher education programmes.

According to Seers et al (2014), these four models, especially the multisided and unbundled open business models, when combined with the facilitated network models, hold great promise for improving the performance of higher education, including that of universities. 
While Seers and his colleagues' typology is relevant, the tripartite categorization of business models by an anonymous author (ey.com...uicf...evolutionary...possibilities 2014) (Ernest \& Young Global Ltd., UK) seems to be more related, useful and applicable in universities. They are streamlined status quo, niche dominators and transformers.

1. Streamlined Status quo. In this model, the university will continue to:

- Serve a broad mix of student segments.

- Offer a broad range of disciplines, but discontinues a small number of subscale/unprofitable disciplines (or merges those disciplines with a competitor institution to achieve scale) providing the resources required to maintain international competitiveness in other disciplines.

- Invest heavily in digital sales and delivery channels and blended channels

- Form a range of sales and delivery partnerships with public and private higher education providers.

- Outsource some back-office functions to realize lower operating costs and/or drive efficiencies through shared services arrangements with like-minded institutions (ey.com...uicf,...2014:1)

2. Niche Dominators. In this model, some established universities and new entrants will:

- Focus on or target particular customer segments with tailored education, research and related services.

- Significantly reduce their range of education disciplines, creating a focused set of areas of genuine domestic and global strength and credibility.

- Build deep alliances with industry in its chosen fields, including partnerships to support R \& D, commercializing research and innovation, professional skill development, and lifelong learning.

- Streamline its back office, including outsourcing and/or shared services models to drive efficiency and economies of scale (ey.com...uicf...2014:2)

3. Transformers: According to ey.com...uicf...(2014), in this model, innovators will:

- Extend the definition of a higher education customers (clients) to include content wholesalers, content consumers, financiers, employers or parents.

- Disaggregate the value chain to create new areas of specialization, assessment and certification.

- Combine traditional education services with services in related industries, such as media and entertainment, financial services and venture capital.

- Build a sales model that is predominantly digital and build delivery models that combine digital services and specialist 'face to face' services sourced from partners.

- Outsource student services, while retaining ownership of their customer relationships.

- Outsource their full suite of back-office functions (ibid, p.2)

\section{Applicability of Business Models in Universities in an Era of Underfunding}

The concept of business model in higher education became very popular during the last decade of the $20^{\text {th }}$ century when it became a "unit of analysis for explaining new ways of doing business" (Lambert 2014). All higher educational institutions, whether for-profit or non-profit, have a business model (Rubin, 2013) and at their core, they address two basic questions thus:

(i) How do we sustainably deliver value to our clients (customers)?

(ii) How can we deliver value so that you are still around in the future? (Kastelle, 2014).

Rubin (2013) reminds us that a "business model"

Does not mean that organizations are designed or operated like traditional businesses with a goal to maximizing profits; it refers to the way that an organization meets people's needs, operates and organizes itself to produce its products or services, and manages its costs and expenses to remain solvent (p.3).

Besides, it has been argued that every business or organization needs "at least one solid business model" (Ingram, 2014). As Hans Isakson (2014) rightly observed, whether we like it or not, universities share a great deal with business especially the non-profit business. In addition, Kastelle (2014), stated that there are many models of business out there and that you can use whichever that makes the most sense to you. But it is important to use one.

Similarly, Hauptli (2012) argued that: 


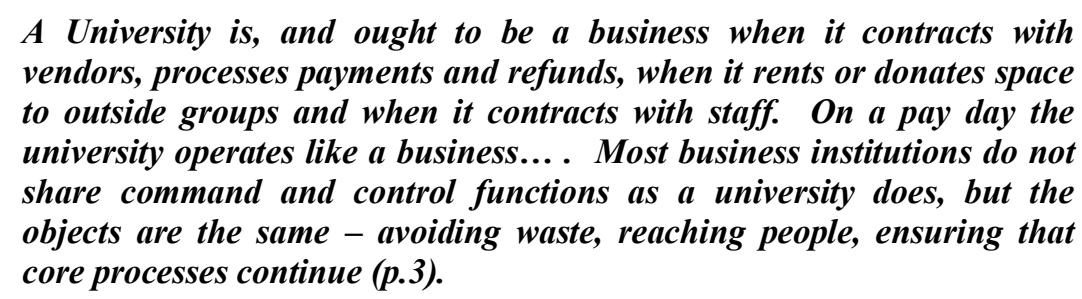

From the foregoing, it can be argued that the use of a carefully selected and application of a well thought-out transformed business model is a fundamental requirement and its application in management of universities is highly desirable in the university system in an era of dwindling State funding of these institutions.

\section{Criticisms of the Business Model}

There are a number of criticisms associated with the application of the Business models in universities. It has been argued that the business model prizes "customer satisfaction" or efficiency and profit - and when the business model is imposed, worthy academic programmes are eliminated based on low enrolment alone. The result is that the arts or humanities and consequently the humanities that are crucial for the development and acquisition of liberal education (Katopes, 2009) are threatened as they become targets for closure. It is for reasons such as these that it has been argued that the business model is a wrong one and that universities should develop the "education model".

The Association (2012) argued that the business model is not appropriate because public universities not only don't generate profits, they "sell" their products at a substantial loss, since their business is in improving people, expanding knowledge, encouraging scholarship and artistic creation, preserving culture, and serving communities (p.1). The Association however, failed to tell the reader how much "substantial loss" should be allowed and for how long? In a situation such as in Nigeria where government funding of Universities has continued to dwindle and universities are being disallowed from collecting tuition fees, the universities are gradually and steadily grounding to a halt and/or excellence far away from their rearch. To survive, therefore, the universities cannot for too long shy away from adopting the business model carefully in university management.

\section{The Advantages}

The benefits of an adopted and appropriately implemented and maintained business model in university are legion. Such a model can help the organization to "refine their processes to eliminate waste and any unnecessary steps in business processes" and provide it with a level of organization to ensure information flows smoothly through the company (Vitez, 2014). A good business model also helps to give a company a competitive advantage as it gives the company the ability to produce goods and services better than other organizations in the economic market.

Besides, a robust business model contributes to organizational sustainability and consequently its ability to weather economic storms. It can give your organization a unique reputation in the market place (Ingram, 2014:1). And Hauptli (2012) is of the view that "its simplest and most defensible form is business model's ability to making sure that there are adequate resources (more than cost) for achieving the mission of the institution. It helps to make sure that an organization makes prudent use of available resources. Similarly, business models are important tool that can be used to "augment product and services, innovations, to link innovations to strategy, to coordinate activities within an organization and can serve as a source of innovation as well" (Birkinshaw, 2011).

\section{Implications for University Management}

A good understanding and deep knowledge of the elements and principles of business models, especially, innovative business models is crucial in navigating through an era of underfunding of universities. Important in this regard is the ability to know and apply the implications of business models in the running and management of higher education institutions. Some of the implications are identified as follows:

1. Using multiple technologies that are cost savings in the core missions of a university such as in teaching and learning and research activities. The use of online teaching (or combining online learning with new operational practices) to extend access and increase efficiency cannot be overemphasized. For example, Allen and Seaman (2013) have reported that as of fall 2011, over 6.7 million post secondary students, representing $32 \%$ of those in the U.S., took at least one online course. 
2. Increased focus on effective teaching and student support services that will lead to students satisfaction and retention (Lubbers, 2013; Rivera, 2013; York, 2013).

3. Working hard with stakeholders to attract and institute huge endowment funds. For example, university of Harvard has an endowment of over 33 billion dollars $(\$ 33 b)$ and the earnings from the yields of this fund in a single year is said to far exceed funds that is raised by Harvard's development officers in five years (Harney, 2013).

4. Using brilliant graduate assistants, senior caliber lectures and retired but strong professors as adjuncts for teaching to reduce expenses.

5. Selecting and designing courses to respond to and meet certain market demands.

6. Reducing funding for overall operations and taking certain money -saving measures. For example, Bradshaw (2013) reported that the University of Alberta took steps to close twenty arts programmes and suspended enrolment into academic majors such as languages and music in an effort to cope with substantial budget shortfalls. Mount Royal University in Calgary also announced the suspension of eight programmes in April 2013 including a theatre - Arts diploma and a journalism certificate. Both universities, the author added, planned to use the cuts as a way of "reinvesting their resources in what they do best", and in maintaining excellence.

Similarly, in the U.K. a number of Universities offering modern languages degrees plunged from 105 in 2000 to 62 at the start of the 2012/2013 academic year because of plummeting of the popularity of the subject and humanities courses in general (Boffey, 2013). Dandridge (2013) pointed out that the laws of demand and supply were inevitable and did force universities to examine their resources and to take difficult decisions in relation to courses which have low student intakes and are unviable. This is the idea of a business model as a guide in management. This, however, is not to suggest that "you clean up the budgets of non-producing budgets (Joseph, 2013) as may be suggested by a pure business position."

7. Transparency in budgeting and clarity of the cost estimate of the different activities, functions and programmes of university and building a sustained focus on measureable performance outcomes could lower costs and improve services and service delivery in higher education (changing higher education.com, 2014).

8. Establishing a consortia also referred to a resource sharing with other universities so as to arrange to be using common facilities and equipment. This will no doubt lead to great savings in the short and long terms.

9. Outsourcing, that is, contracting out of certain duties to a third party. Such functions include outsourcing maintenance of university plants and grounds, secretarial duties, security, transportation and student services.

10. Prioritizing is crucial in times of economic down turn.

11. Building strategic alliances and partnership with industry in specialized fields and to support research and development (R\&D) and professional skills development with industry and government establishments.

12. Commercializing research and innovation.

\section{Conclusion}

Higher education is in a state of flux. Public universities in Nigeria are faced with infrastructural decay. Vital facilities for teaching and learning and laboratory and workshop equipment are lacking and/or obsolete. Similarly, funds for research and innovations and development are in short supply. There is increasing need for funds to construct new facilities and meet dire needs. Funds required to engage the services of required faculty in terms of quantity, quality and the right mix is also a major challenge. Despite this great need that calls for adequate funding of these public universities, their proprietors have become tighter fisted, reducing their funding to these universities.

The above scenario demands that managers of universities need to fundamentally adopt a business model that will enable them to survive in the face of the threatening financial strangulation. An adoption of a reformed business model may be the solution to the financial problems and to move beyond the creepling struggle for funds. A good business model will help the university chief executives to diversify their funding sources, sustain its funding sources, generate enough revenue, increase its productivity, sustain itself and become more effective and efficient. It must prudently utilize funds so generated and consequently become less dependent on government funding. An application of an appropriate business model is vital also to avoiding waste, and for managing organizational "costs and expenses" so as to remain solvent. But if chief executives of these universities and their staff must devote their time, effort and energy towards revenue generation, the vision, mission, goals and objectives of these institutions may be far from being achieved as their primary functions will suffer. Therefore, the federal and state governments should, as a matter of policy, continue to 
maintain an adequate funding levels of their universities because of the very important role they play in the socio-economic, political and technology development of the country.

\section{References}

[1]. Balaji, V. (2011). How to build revenue: 24 types of business models with examples. htt://. The Agni.com December $2^{\text {nd }}$

[2]. Birkinshaw, Julian (2011). What is your management model? Opensource.com posted February $28^{\text {th }}, 2011$

[3]. Boffey, Daniel (2013). Language teaching crisis as $40 \%$ of University departments face closure. The Observer, Saturday $17^{\text {th }}$ August.

[4]. Bradshaw, James (2013). University of Alberta eliminates 20 arts programmes. The Globe and Mail, August 19, 2013

[5]. Chesbrough, H. (2003). Open Innovation: the new imperative for creating and profiting from technology. Boston: Harvard Business School Press.

[6]. Chesbrough, H. and Rosenbloom, R.S. (2002). The role of the business model in capturing value from innovation evidence from Xerox Corporations technology spinoff companies." Industrial and Corporate change, 11(3), 529-555.

[7]. Dandridge, Nicola (2013). "Chief Executives of Universities UK, representing Britain's higher education sector". Quoted in Boffey (2013). Language Teaching crises as $40 \%$ of University departments face closure. The Observer, Saturday $17^{\text {th }}$ August, p.3

[8]. Ernest \& Young Global (2014): Evolutionary possibilities for University business models:www.ey.com/.../UOF-Evolutionarypossibilities.retrieved July $2^{\text {nd }}, 2014$

[9]. Ey.com.uicf. (2014). Higher Education Institutions will need to fundamentally transform their business models to survive, according to an Industry wide study of Australia he. (November $16^{\text {th }}, 2012$ ). Retrieved June $26^{\text {th }}$.

[10]. Harney, John O. (2013). Explaining higher Education Business Models (if such a Thing Exists). The New England Journal of Higher Education. October $8^{\text {th }}, 2013$

[11]. Hartman, Mitch (104). Financing the University in a post-2015 world. University world News, March $09^{\text {th }} 2014$. Issue No311

[12]. Hauptli, Bruce W. (2014). Business Models are inappropriate for University Committees. www.2.fiu.edu/-hauptli/Business Models Are Inappropriate for University Communities.htm.retrieved July $1^{\text {st }}, 2014$

[13]. Ingram, David (2014). The Advantages of a Business Model. www.smallbusiness.chron.com.retrieved July $04^{\text {th }}, 2014$

[14]. Joseph, Norma B. (2013). Opinion: Can a business model help universities? The Bazette Montreal Gazette. Com., January $28^{\text {th }}$.

[15]. Kastelle, Tim (2014). Eight Models of Business Models and Why they're important. Timastelle.org.retrieved July $03^{\text {rd }}, 2014$

[16]. Katopes, Peter (2009). The "Business Model" Is the Wrong Model. Inside Higher Education, February $16^{\text {th }}$.

[17]. Lambert, Susan (2014). Business Models. htp.//www.audiencedaialogue.net/document/Businessmodels-lambert-ooo.pdf retrieved July $06^{\text {th }} 2014$

[18]. Mayo, M.S. and Brown, G.S. (1999). Building a Competitive Business Model. Ivey Business Journal, 63(3):18-23

[19]. Nelson, Drew (2011). Four Basic Business Models. Voices-yahoo.com/four-basic-business-models-htm/retrieved July $04^{\text {th }}, 2014$

[20]. Osterwalder, A., Pigneur, Y. and Tucci, C. L. (2005). "Clarifying business models: Origins, present, and future of the concept". Communications of the Association of Information Systems. 16,1-40

[21]. Pham, Hiep (2013). Ministry orders cuts in enrolments to boost quality. University World News. April $2^{\text {nd }}$, 2013, issue No:00265

[22]. Pitman, Tim (2013). Funding cuts pose challenges for the University Business Model. The Conversation.com/funding-cutspole.retrieved May $10^{\text {th }}, 2014$

[23]. Rubin, Beth (2013). University Business Models and Online Practices: A third way.www.westga.edu/-distance/ojdia/springrubin.html.retrieved July $03^{\text {rd }} 2014$

[24]. Russiga Guages Universities by graduate employment. University World News, April 2 ${ }^{\text {nd }}, 2013$, Issue No: 00265

[25]. Shafer, Smith and Linder (2005). "The power of business models". Business Horizons, 48(3), 195-199

[26]. Sheets, R., Crawford, S., and Soares, L. (2012). "Re-think Higher Education Business Models". Center for American progress, March $28^{\text {th }}, 2012$.

[27]. Slywotzky, A.J. (1996). Value Migration. Boston, MA: Harvard Business Review press.

[28]. The Association of Governing Boards of Universities and Colleges (1998). Draft statement "On Institutional Governance", as it appeared on their web-site on September $7^{\text {th }}$.

[29]. The Daily Orange Editorial Board (2013). Business Model benefits higher education, advances University resources daily organge.com.

[30]. Vitez, Osmond (2014). What are the benefits of the business model? Ehow.com retrieved July $03^{\text {rd }}, 2014$ 